\title{
PENGARUH KEDALAMAN ELEKTRODA TERHADAP PENGUKURAN TAHANAN JENIS TANAH, PASIR DAN AIR LAUT DI PULAU AMBON DENGAN KONFIGURASI WENNER ALFA
}

\author{
Vicky Salamena \\ Jurusan Teknik Elektro Politeknik Negeri Ambon \\ vickys@polnam.ac.id
}

\begin{abstract}
Soil resistivity is essential in determining the earthing system of electrical power system equipment such as power stations or power stations. From the measurement results of soli resistivity can be determined grounding resistance that can be used to determine the grounding system (electrical equipment).This study intends to measure materia soil, sand and sea water level in Ambon Island by the method of Wenner Alfa. Measurements were performed with variations in depth electrode from $1 \mathrm{~cm}$ up to $8 \mathrm{~cm}$ with $4 \mathrm{~cm}$ electrode spacing. The measurement results for soil V/I resistance the electrode is smaller to a depth smaller than the electrode distance, for the depth of the electrode greater than the electrode distance from the measurement of the V/I constant resistance. The measurement results of soli resistance did not affect the depth of electrode. The results of calculation of soil resistevity from measurement with electrode change from $1 \mathrm{~cm}$ up to $8 \mathrm{~cm}$ ranged from $4,000 \Omega \mathrm{cm}$ to $6,000 \Omega \mathrm{cm}$ whose mean is about $5,300 \Omega \mathrm{cm}$, the soil resistivity remains constant with the addition of depth electrode. Measurement for sand material shows that the electrode depth is less than $4 \mathrm{~cm}$. The value of $\mathrm{V} / \mathrm{I}$ resistance is constant. For the depth of the electrode greater than the electrode distance the value of the V/I resistance increases with proportional to the eletrode state. The type of sand resistance is constant at a depth smaller than the eletrode distance. Measurement of V/I resistance of seawater constant at eletrode depth is smaller than the distance of electrode, then it will decrease when electrode deepens. The deeper the eletrode, the greater the resistance of the seawater type to the electrode's proximity smaller than the distance of the electrode, to the depth of the eletrode greater than the distance of the electrode measuring the resistivity of the type of seawater resistance.
\end{abstract}

Tahanan jenis tanah sangat diperlukan dalam menentukan sistem pentanahan pada peralatan sistem tenaga listrik seperti di stasiun pembangkit atau gardu listrik. Dari hasil pengukuran tahanan jenis tanah dapat ditentukan tahanan pentanahan yang dapat dipakai untuk menentukan sistem pentanahan (grounding) peralatan listrik tersebut. Penelitian ini bermaksud mengukur tahanan jenis dengan material tanah, pasir dan air laut di pulau Ambon dengan metoda Wenner Alfa. Pengukuran dilakukan dengan variasi kedalaman elektroda dari $1 \mathrm{~cm}$ sampai dengan $8 \mathrm{~cm}$ dengan jarak elektroda $4 \mathrm{~cm}$. Hasil pengukuran untuk tanah makin dalam elektroda tahanan V/I makin kecil untuk kedalaman lebih kecil dari jarak elektroda, untuk kedalaman elektroda lebih besar dari jarak elektroda hasil pengukuran tahanan V/I konstan. Hasil pengukuran tahanan jenis tanah tidak berpengaruh terhadap kedalaman eletroda. Hasil perhitungan tahanan jenis tanah dari pengukuran dengan perubahan elektroda dari $1 \mathrm{~cm} \mathrm{~s} / \mathrm{d} 8 \mathrm{~cm}$ berkisar antara $4.000 \Omega \mathrm{cm}$ s/d $6.000 \Omega \mathrm{cm}$ yang reratanya berkisar $5.300 \Omega \mathrm{cm}$, tahanan jenis tanah nilainya tetap konstan dengan penambahan kedalaman elektroda. Pengukuran untuk material pasir menunjukkan bahwa kedalaman elektroda lebih kecil dari $4 \mathrm{~cm}$ nilai tahanan V/I konstan. Untuk kedalaman elektroda lebih besar dari jarak elektroda nilai tahanan V/I meningkat sebanding dengan kedalman eletroda. Tahanan jenis pasir bernilai konstan pada kedalaman lebih kecil dari jarak eletroda. Pengukuran tahanan V/I air laut konstan pada kedalaman eletroda lebih kecil dari jarak elektroda, Selanjutnya akan mengecil bila elektroda semakin dalam. Semakin dalam eletroda, tahanan jenis air laut makin besar untuk kedalaman elektroda lebih kecil dari jarak elektroda, untuk kedalaman eletroda lebih besar dari jarak elektroda pengukuran tahanan tahanan jenis air laut semakain kecil.

Kata kunci: resistivity; wenner-alfa; elektroda

\section{PENDAHULUAN}

Untuk membuat suatu sistem pentanahan jenis batang (rod) diperlukan kedalam tertentu agar mendapatkan nilai tahanan pentanahan yang dibutuhkan, semakin dalam batang pentanahan ditanam kedalam tanah semakin kecil nilai tahanan tanahnya, (WahyonodanBudhiPrasetyo). Demikian pula semakin kecil nilai tahanan pentanahan, maka pentanahan tersebut semakin baik. Menurut Aris
Sunawar (2013) tahanan pentanahan dipengaruhi oleh tahanan batang pentanahan, tahanan kontak antara batang pentanahan dengan tanah dan tahanan jenis tanah. Pada kenyataannya tanah terdiri dari berbagai material yang membentuk lapisan-lapisan tertentu. Menurut Rina Dwi Indriani dan Hernowo Danusaputro (2006), tahanan jenis tanah tergantung dari material tersebut sehingga setiap lapisan tanah mempunyai nilai tahanan jenis tersendiri. Untuk 


\section{JURNAL SIMETRIK VOL.8, NO.1, JUNI 2018}

mengetahui nilai tahanan pentanahan perlu diketahui lebih dahulu tahanan jenis tanah sehingga dapat dipakai untuk mendesain sistem pentanahannya.

Ada beberapa metode yang digunakan untuk mengukur tahanan jenis tanah yaitu metoda dengan menggunakan tiga elektroda dan empat elektroda. Metoda yang sederhana dalam pemakaiannya adalah metoda Wenner. Metoda Wenner mempunyai empat elektroda yang disusun dalam beberapa konfigurasi, konfigurasi dengan jarak setiap elektroda sama disebut dengan metoda Wenner Alfa. Pada metoda ini ada empat elektroda yaitu dua elektroda arus dan dua elektroda potensial. Makin besar jarak elektroda maka arus listrik akan jauh masuk kedalam tanah sehingga makin banyak lapisan tanah yang dialiri oleh arus listrik, demikian juga makin dalam elektroda maka tahanan kontak antara elektroda dengan tanah makin banyak sehingga mempengaruhi tahanan pengukuran (tegangan per arus). Dengan makin dalam elektroda maka makin banyak pengaruh material tanah yang terlingkupi dalam pengukuran sehingga dapat juga mempengaruhi hasil pengukuran tahanan jenis tanah.

Berdasarkan nilai tahanan jenis maka material yang ada di Bumi telah diklasifikasikan kedalam jenisjenis tertentu sehingga bila ada material pada suatu daerah yang mempunyai nilai tahanan jenis tersebut dapat diklasifikasikan kedalam klasifikasi yang ada pada acuan tersebut. Berdasarkan hubungan ini daerah kepulauan seperti di Provinsi Maluku khususnya di pulau Ambon yang terbentuk dari aktivitas teknonik dapat mempunyai struktur tanah atau pasir yang mempunyai nilai tahanan jenis yang dapat digolongkan sesuai klasifikasi acuan yang ada. Dalam penelitian ini adalah bagaimana mendapatkan klasifikasi material tanah, pasir dan air laut dari nilai pengujian tahanan jenisnya. Pengujian dilakukan dengan metoda Wenner Alfa yang jarak antar keempat elektrodanya sama. Penelitian ini bertujuan mengukur tahanan pengukuran tegangan per arus dari metoda
Wenner Alfa dengan merubah kedalaman elektroda, menghitung tahanan jenis tanah berdasarkan konfigurasi Wenner dan mendapatkan klasifikasi dari material uji sesuai acuan.

\section{TINJAUAN PUSTAKA \\ 2.1 Metode Geolistrik}

Penggunaan geolistrik pertama kali dilakukan oleh Conrad Schlumberger pada tahun 1912. Geolistrik merupakan salah satu metoda geofisika untuk mengetahui perubahan tahanan jenis lapisan batuan di bawah permukaan tanah dengan cara mengalirkan arus listrik DC (direct current) yang mempunyai tegangan tinggi kedalam tanah. Injeksi arus listrik ini menggunakan 2 buah 'ElektrodaArus' A dan B yang ditancapkan kedalam tanah dengan jarak tertentu. Semakin panjang jarakelektroda $A B$ akan menyebabkan aliran arus listrik bias menembus lapisan batuan lebihdalam.

Dengan adanya aliran arus listrik tersebut maka akan menimbulkan tegangan listrik di dalam tanah. Tegangan listrik yang terjadi di permukaan tanah diukur dengan penggunakan multimeter yang terhubung melalui 2 buah 'Elektroda Tegangan' M dan $\mathrm{N}$ yang jaraknya lebih pendek dari pada jarak elektroda AB. Bila posisi jarak elektroda AB diubah menjadi lebih besar maka tegangan listrik yang terjadi pada elektroda $\mathrm{MN}$ ikut berubah sesuai dengan informasi jenis batuan yang ikut terinjeksi arus listrik pada kedalaman yang lebih besar. Dengan asumsi bahwa kedalaman lapisan batuan yang bias ditembus oleh arus listrik ini sama dengan separuh dari jarak $\mathrm{AB}$ yang biasa disebut $\mathrm{AB} / 2$ (bila digunakan arus listrik DC murni), maka diperkirakan pengaruh dari injeksi aliran arus listrik ini berbentuk setengah bola dengan jari-jari $\mathrm{AB} / 2$.

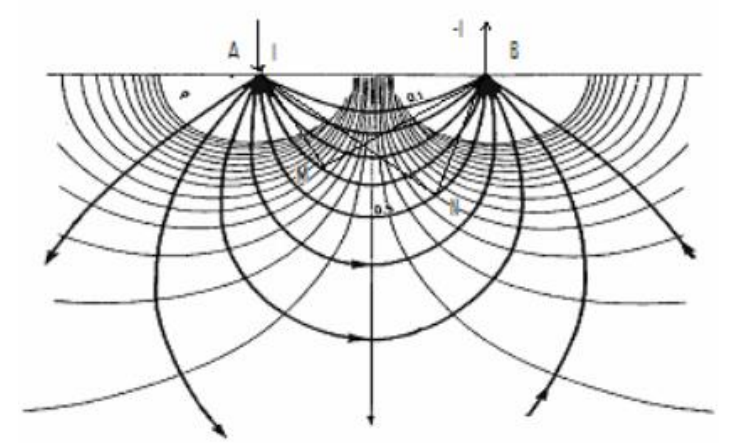

Sumber: Bulkis Kanata, Teti Zubaidah, 2008

\section{Gambar 1 Cara Kerja Metode Geolistrik}

Umumnya metodageolistrik yang sering digunakan adalah yang menggunakan 4 buah elektroda yang terletak dalamsatu garis lurus serta jarak $\mathrm{AB} / 2$, jarak $\mathrm{MN} / 2$, besarnya arus listrik yang dialirkan serta tegangan listrik yang terjadi akan didapat suatu harga tahanan jenis semu (apparent simetris terhadap titik tengah, yaitu 2 buah elektroda arus (AB) di bagian luar dan 2 buah elektroda tegangan $(\mathrm{MN})$ di bagian dalam.Kombinasi dari resistivity). Disebut tahanan jenis semu karena tahanan jenis yang terhitung tersebut merupakan gabungan 


\section{JURNAL SIMETRIK VOL.8, NO.1, JUNI 2018}

dari banyak lapisan batuan di bawah permukaan yang dilalui arus listrik.

Bila satu set hasil pengukuran tahanan jenis semu dari jarak $\mathrm{AB}$ terpendek sampai yang terpanjang tersebut digambarkan pada grafik logaritma gandadengan jarak $\mathrm{AB} / 2$ sebagai sumbu-X dan tahanan jenis semu sebagai sumbu Y, maka akan didapat suatu bentuk kurva data geolistrik. Dari kurva data tersebut bisa dihitung dan diduga sifat lapisan batuan di bawah permukaan.

\section{.Konfigurasi Elektroda Wenner}

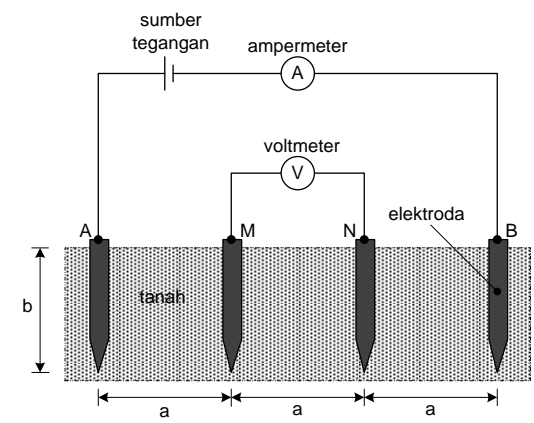

Sumber: Aris Sunawar, 2013

\section{Gambar 2. Skema konfigurasi Wenner}

Konfigurasi Wenner digunakan pada jarak yang sama antara elektroda. Dalam konfigurasi ini $\mathrm{AM}=\mathrm{MN}=\mathrm{NB}$. Pada konfigurasi ini persamaan relativitasnya menjadi,

$\rho=K \frac{\Delta V}{I}$

dan

$K=2 \pi a$

dengan

$\rho \quad:$ tahananjenis tanah $[\Omega \mathrm{m}]$,

$K$ : faktorkonfigurasi,

$\Delta V$ : teganganterukur pada elekroda MN [V],

I : arusterukur padaelektroda $\mathrm{AB}[\mathrm{A}]$,

a : jarakantar elektroda [m].

Pada konfigurasi ini, jarak antar elektroda (a) harus seragam untuk setiap pengukuran dikategorikan sebagai Metoda Wenner Alfa.Susunan ini sangat cocok dan efisien untuk mengetahui perbandingan tegangan yang masuk per unitnya dari arus yang mengalir.Pada kondisi yang tidak baik seperti, tanah kering atau tanah padat membutuhkan waktu yang lama untuk mengetahui kontak tahanan antara elektroda dengan tanah.Tahanan Jenis Tanah dengan metode Wenner Alfa dapat dihitung dengan persamaan (3).

$$
\rho=\frac{4 \pi a R}{1+\frac{2 a}{\sqrt{a^{2}+4 b^{2}}}-\frac{a}{\sqrt{a^{2}+b^{2}}}}
$$

dengan:

$$
\begin{array}{ll}
\rho & : \text { tahananjenis tanah }[\Omega \mathrm{m}], \\
a & : \text { jarakantar elektroda }[\mathrm{m}], \\
b & : \text { kedalamanelektroda }[\mathrm{m}], \\
R & : \text { resistanselektroda }
\end{array}
$$

$$
\mathrm{MN}=\frac{\Delta V}{I}[\Omega]
$$

\subsection{Pengaruh Kedalaman Elektroda}

Bila elektroda di tanam didalam tanah dan arus listrik diberikan pada elektroda tersebut akan terjadi gradien tegangan yang arahnya radial terhdap elektroda tersebut. Gradien tegangan ini dipengaruhi oleh kedalaman elektroda, sehingga bila ada dua elektroda yang berdekatan maka akan terjadi saling tumpang-tindih (overlapping) dari gradien tegangan kedua elektroda tersebut. Ilustrasinya diperlihatkan pada gambar 3 .

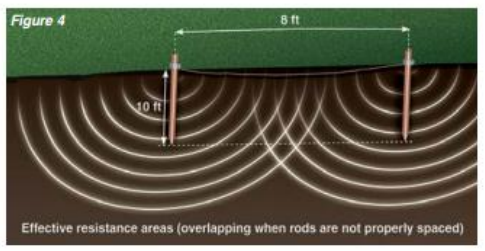

Sumber:AEMC instrument, 2017

Gambar 3 Gradien tegangan yang tumpang-tindih

Yang menimbulkan gradien atau perbedaan tegangan ini adalah kontak antara batang elektroda dengan tanah disekelilingnya yang tahanan tanahnya berbeda.Nilai tahanan tanah pada areal ini tidak konstan dan makin dalam elektroda maka areal gradien tegangan ini makin luas. Bila jarak elektroda melebihi daerah tumpang-tindih ini maka tahanan tanah akan konstan terhadap jarak kedua elektroda tersebut. Ilustrasi kondisi ini ditunjukkan olehgambar 4.

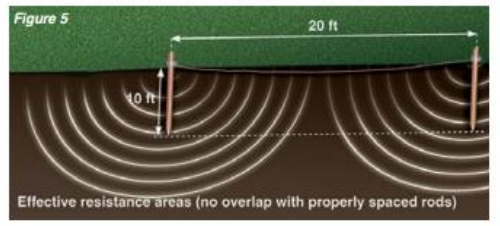

Sumber:AEMC instrument, 2017

\section{Gambar 4 Jarak elektroda diluar daerah tmpang-} tindih

Berdasarkan kedua venomena di atas maka menurut Lighting and Surge Publications (sub-bab: Earthing Techniques, halaman 22), bahwa nilai tahanan fungsi jarak radial antara dua elektroda dengan kedalaman berbeda ditunjukkan oleh gambar 5 . 


\section{JURNAL SIMETRIK VOL.8, NO.1, JUNI 2018}

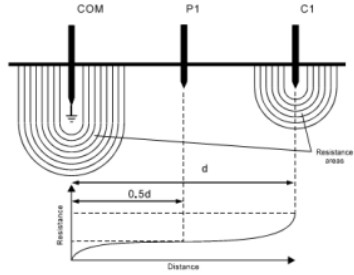

Sumber: Earthing Techniques, 2017

\section{Gambar 5 Kurva resistansi tanah fungsi jarak}

Dari kurva ini terlihat bahwa makin dalam batang elektroda gradien tegangan makin luas dan diluar area gradien tegangan tahanan tanah konstan.Ini memperlihatkan bahwa ada pengaruh dari jarak penempatan elektroda ukur dengan kedalamannya.Nilai resistans konstan untuk batang elektroda yang lebih dalam kisarannya nilainya lebih sempit dari batang elektroda yang lebih dangkal.

\section{METODOLOGI PENELITIAN}

Penelitian ini dilakukan dengan melakukan studi pustaka sehingga membentuk landasan ilmiah yang dapat digunakan untuk memodelkan persoalan fisik tanah yang mempengaruh pengukuran tahanan jenis tanah dengan metoda Wenner Alfa. Selanjutnya dilakukan pengujian dengan membuat simulasi kondisi tanah dalam wadah tertentu dan membuat konfigurasi elektroda pengkuran model Wenner untuk penempatan elektroda pada wadah tersebut.

\subsection{Pembuatan Wadah}

Membuat simulasi tanah pada suatu wadah dengan bentuk/geometrik dan ukuran seperti gambar 6.

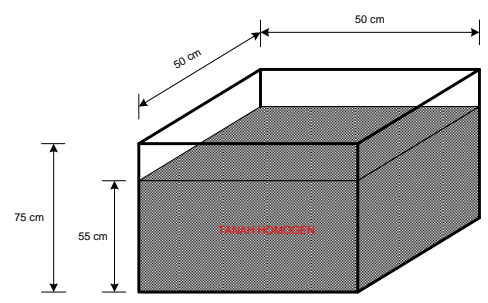

Sumber: Peneliti, 2017

\section{Gambar 6. Wadah simulasi tanah}

\subsection{Pembuatan Konfigurasi Batang Elektroda}

Membuat Konfigurasi batang eletroda metoda Wenner Alfa dengan jarak elektroda sama ditunjukkan oleh gambar 7.

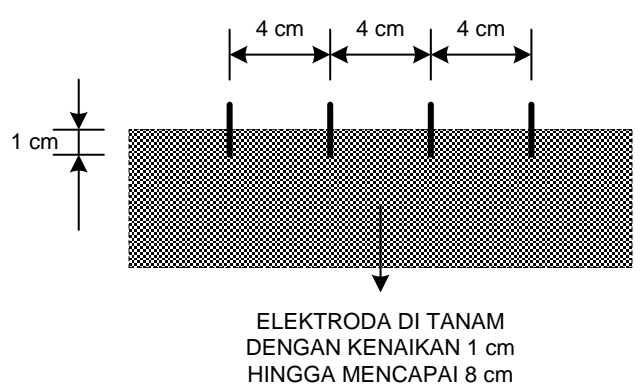

Sumber: Peneliti, 2017

\section{Gambar 7. Konfigurasi Elektroda pengukuran tahanan jenis tanah}

Berdasarkan hubungan antara variabel kedalam elektroda dan tahanan jenis tanah akan dibuat grafik yang dapat memperlihatkan karakteristik dari hubungan tersebut. Dari karakteristik ini dapat ditentukan fenomena tersebut dan ditarik kesimpulannya.

\section{HASIL DAN PEMBAHASAN}

Pengambilan data dilakukan terhadap Pasir, Tanah dan Air laut, yang ditempatkan dalam wadah seperti ditunjukkan oleh gambar 8 .

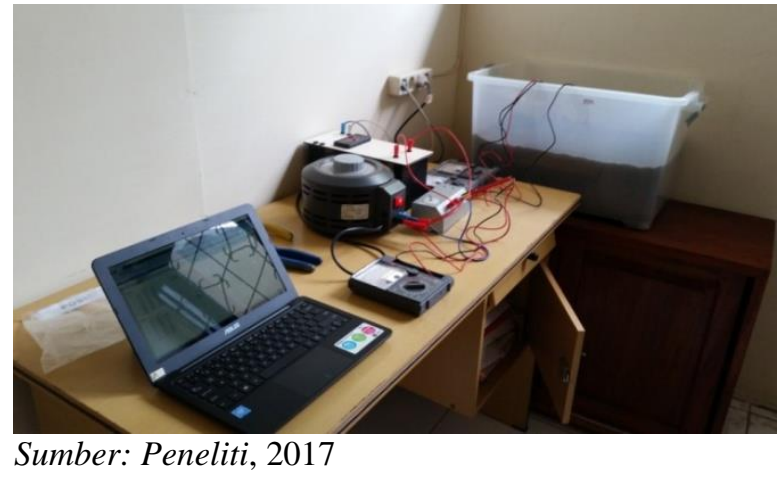

Gambar 8. Rangkaian pengambilan data

Pengukuran dilakukan sebanyak 8 posisi di dalam wadah seperti ditunjukkan pada gambar 9 .

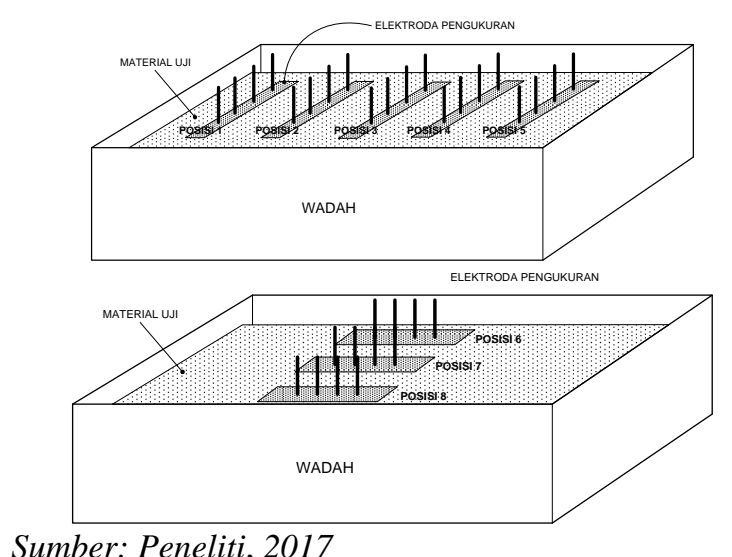

Gambar 9. Posisi pengukuran di dalam wadah 


\section{JURNAL SIMETRIK VOL.8, NO.1, JUNI 2018}

\subsection{Pengukuran Tahanan Jenis Tanah}

Hasil pengukuran untuk tanah yang telah dirataratakan dari delapan posisi tersebut ditampilkan dalamtabel 1.Pengukuran dilakukan terhadap panjang elektroda dari $1 \mathrm{~cm}$ sampai dengan $8 \mathrm{~cm}$ dengan kenaikan $1 \mathrm{~cm}$.

Tabel 1 Hasil pengukutan $\mathrm{V}$ dan I Tanah

\begin{tabular}{|c|c|c|c|c|}
\hline $\mathrm{B}$ & $\mathrm{V}$ & $\mathrm{I}$ & $\mathrm{R}=\mathrm{V} / \mathrm{I}$ & $\rho$ \\
\hline 1 & 2.325 & 11.875 & 195.789 & 5411.17 \\
\hline 2 & 3.354 & 23.563 & 142.334 & 4707.52 \\
\hline 3 & 4.050 & 26.125 & 155.024 & 5951.03 \\
\hline 4 & 4.413 & 36.563 & 120.684 & 5109.13 \\
\hline 5 & 5.325 & 55.875 & 95.302 & 4284.42 \\
\hline 6 & 6.088 & 48.125 & 126.494 & 5899.48 \\
\hline 7 & 6.575 & 55.000 & 119.545 & 5704.86 \\
\hline 8 & 6.788 & 61.125 & 111.043 & 5377.98 \\
\hline
\end{tabular}

Sumber: Peneliti, 2017

Grafik yang dihasilkan dari tabel 1 ditunjukkan oleh kurva gambar 10.

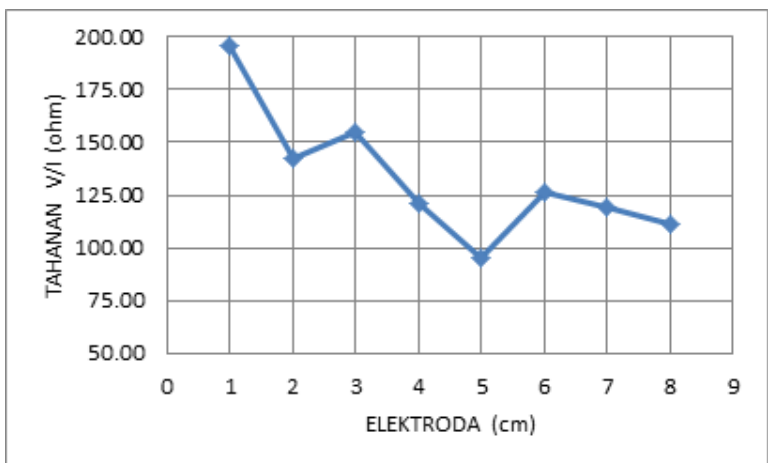

Sumber: Peneliti, 2017

\section{Gambar 10. Kurva kedalamam elektroda vs tahanan pengukuran $\mathrm{V} / \mathrm{I}$ tanah}

Dari kurva tersebut terlihat bahwa makin dalam elektroda nilai tahanan V/I makin kecil pada selang kedalaman elektroda (B)lebih kecil dari jarak eletroda (a). Hal ini karena makin dalam temperatur tanah makin kecil dan kelembaman tanah makin besar sehingga tahanan tanah makin kecil. Untuk hasil pengukuran dari 4-cm sampai 8-cm (lebih besar dari jarak eletroda, a) hasil penukuran hampir konstan karena terjadi tumpang-tindih (over-lap) antara gradien tahanan di sekitar eletroda.

Selanjutnya dengan menggunakan persaman (3) dapat dihitung nilai tahanan jenis tanah sebagai fungsi dari kedalamam eletroda dan karakteristiknya ditunjukkan oleh kurva gambar 11.

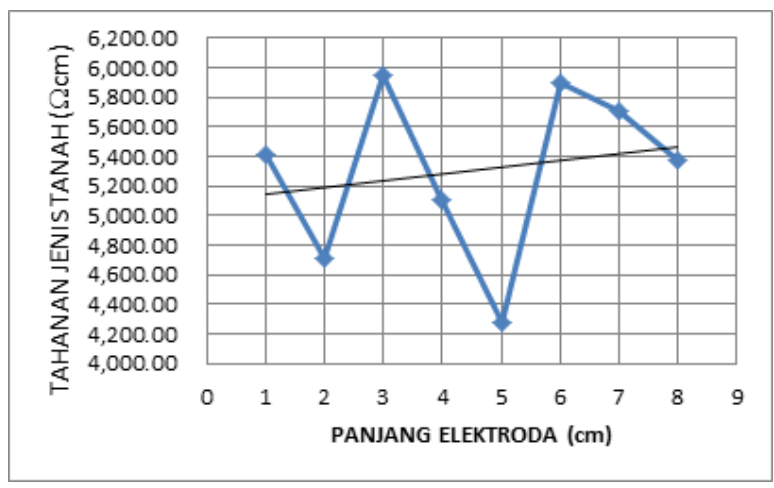

Sumber: Peneliti, 2017

\section{Gambar 11 Kurva kedalaman elektroda vs tahanan jenis tanah}

Hasil perhitungan tahanan jenis tanah dari pengukuran dengan perubahan elektroda dari $1-\mathrm{cm} \mathrm{s} / \mathrm{d}$ 8 -cm berkisar antara $4.000 \Omega \mathrm{cm} \mathrm{s} / \mathrm{d} 6.000 \Omega \mathrm{cm}$ yang reratanya berkisar $5.300 \Omega \mathrm{cm}$. Ini berarti perubahan elektroda tidak terlalu berpengaruh pada tahanan jenis tanah, baik itu panjang elektroda (B) lebih kecil dari jarak eletroda (a). Dari penjelasan teori terbukti bahwa tahanan jenis tanah hanya dipengaruhi oleh jenis dan struktur tanah sehingga tidak dipengaruhi oleh kedalamam elektroda tetapi besar kecil nilainya dapat dipengaruhi oleh temperatur dan kelembaman tanah.Tanah contoh yang diukur mempunyai struktur yang homogen ke arah kedalaman sehingga perubahan kedalaman elektoda tidak berpengaruh terhadap nilai tahanan jenis tanah tersebut.Karena tanah tersebut bercampur batuan dengan komposisi yang merata maka terjadi fluktuasi disetiap kedalaman pengukuran. Menurut Managam Rajagukguk, 2012 (IEEE Std 81 1983) hasil pengukuran tahanan jenis Tanah $5.300 \Omega \mathrm{cm}$ atau $53,00 \Omega \mathrm{m}$ termasuk kategori antara tanah organik dan tanah basah yang nilainya $10-\Omega \mathrm{m}$

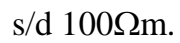

\subsection{Pengukuran Tahanan Jenis Pasir}

Pengukuran terhadap pasir yang dilakukan dalam wadah seperti Gambar 9 menghasilkan nilai yang ditampilkan oleh tabel 2.

Tabel 2.Hasil pengukuran V dan I Pasir

\begin{tabular}{|c|c|c|c|c|}
\hline $\mathrm{B}$ & $\mathrm{V}$ & $\mathrm{I}$ & $\mathrm{R}=\mathrm{V} / \mathrm{I}$ & $\rho$ \\
\hline 1 & 0.126 & 0.119 & $1,063.68$ & $29,397.78$ \\
\hline 2 & 1.311 & 0.263 & $4,993.33$ & $165,148.14$ \\
\hline 3 & 1.813 & 0.394 & $4,603.17$ & $176,705.74$ \\
\hline 4 & 2.297 & 0.575 & $3,994.57$ & $169,109.21$ \\
\hline 5 & 3.863 & 0.581 & $6,645.16$ & $298,741.73$ \\
\hline 6 & 4.388 & 0.563 & $7,800.00$ & $363,781.08$ \\
\hline 7 & 5.538 & 0.669 & $8,280.37$ & $395,150.18$ \\
\hline 8 & 8.025 & 0.975 & $8,230.77$ & $398,628.48$ \\
\hline
\end{tabular}

Sumber: Peneliti, 2017 


\section{JURNAL SIMETRIK VOL.8, NO.1, JUNI 2018}

Grafik hasil pengukuran tegangan $(V)$, arus $(I)$ dan perhitungan tahanan $R=\mathrm{V} / \mathrm{I}$ pada kedalaman elektroda $1-\mathrm{cm} \mathrm{s} / \mathrm{d} 8 \mathrm{~cm}$ yang diperoleh dari Tabel 2 ditunjukkan oleh gambar 12 .

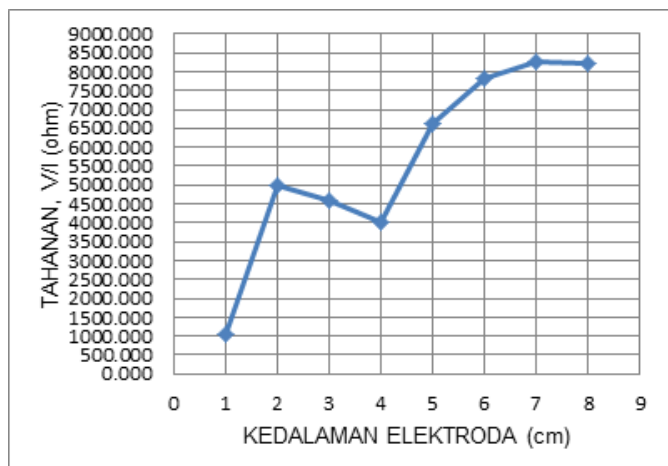

Sumber: Peneliti, 2017

\section{Gambar 12. Grafik tahanan V/I fungsi kedalaman elektroda B}

Pasir yang digunakan adalah pasir laut yang telah dikeringkan secara merata sehingga temperatur dan kelembaman merata di setiap segmen pasir.Hasil pengukuran menunjukkan bahwa kedalaman elektroda lebih kecil dari 4-cm nilai tahanan mendekati konstan, pada posisi elektroda $1 \mathrm{~cm}$ nilainya agak jauh dibawah dikarenakan pendeknya elektroda $(1 \mathrm{~cm})$ sehingga kontak antara eletroda dengan pasir kurang sempurna sehingga timbul hambatan di seputar elektroda yang mengakibatkan arus mengalir dari elektroda ke tanah kecil.Dengan demikian tegangan yang diukur antara elektroda $\mathrm{M}$ dan $\mathrm{N}$ juga kecil.Untuk kedalaman elektroda lebih besar dari jarak elektroda (a) nilai tahanan meningkat sebanding dengan peningkatan tumpang-tindihnya (overlapping) gradien tahanan.

Selanjutnya dari data tahanan V/I, jarak dan kedalaman elektroda diperoleh nilai tahanan jenis tanah yang grafiknya ditunjukkan oleh gambar 13 .

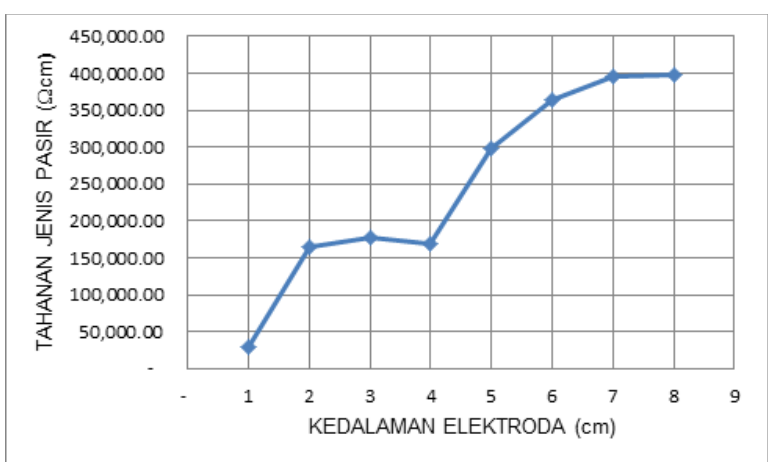

Sumber: Peneliti, 2017

\section{Gambar 13. Kurva tahanan jenis Pasir vs kedalaman elektroda}

Terlihat bahwa tahanan jenis pasir bernilai konstan terutama pada kedalaman 1-cm s/d 4-cm ini menyatakan bahwa pasir tersebut strukturnya homogen. Nilai yang terjadi pada kedalaman $1-\mathrm{cm}$ adalah keterbatasan dari penempatan elektroda yang mengakibatkan kontak antara batang elektroda dan pasir tidak terlalu benar.Nilai tahanan jenis pasir di atas kedalaman 4-cm meningkat akibat telah melebihi jarak elektroda sehingga hasil pengukuran dipengaruhi oleh gradien tahanan di sekeliling elektroda.Jadi sesuai dengan karakteristik pengukuran menggunakan metoda Wenner, maka kedalaman elektroda harus lebih kecil dari jarak elektroda. Dari hasil pengukuran diperoleh tahanan jenis pasir ini berkisar antara $150.000 \Omega \mathrm{cm} \mathrm{s} / \mathrm{d} 200.000 \Omega \mathrm{cm}$ atau $1.500 \Omega \mathrm{m} \mathrm{s} / \mathrm{d}$ $2.000 \Omega \mathrm{m}$. Menurut Jamaaluddin, Izza Anshory, Eko Agus Suprayitno, 2015 (3.18.3.1. PUIL, 2000) termasuk kategori pasir dan kerikil kering dengan nilai $1.000-\Omega \mathrm{m}$.

\subsection{Pengukuran Tahanan Jenis Air Laut}

Air laut yang diambil untuk material contoh diasumsikan strukturnya homogen yaitu partikel garam dan partikel lainya seragam di setiap segmen air laut tersebut.Dengan asumsi tersebut dan mempertimbangkan kesederhanaan pengukuran maka dilakukan hanya 5 posisi saja untuk mewakili keseluruhan permukaan air laut, demikian juga air laut dikondisikan tenang (tidak bersirkulasi) sehingga tidak ada pengaruh pergerakan partikel yang ada di dalam air laut tersebut.Hasil pengukuran tahanan V/I dari kedalaman elektroda $1-\mathrm{cm}$ s/d $8-\mathrm{cm}$ ditunjukkan pada tabel 3 .

Tabel 3. Hasil pengukuran V dan I Air Laut

\begin{tabular}{|c|c|c|c|c|}
\hline $\mathrm{B}$ & $\mathrm{V}$ & $\mathrm{I}$ & $\mathrm{R}=\mathrm{V} / \mathrm{I}$ & $\rho$ \\
\hline 1 & 0.038 & 56.000 & 0.6786 & 18.7541 \\
\hline 2 & 0.104 & 128.000 & 0.8125 & 26.8724 \\
\hline 3 & 0.130 & 156.000 & 0.8333 & 31.9898 \\
\hline 4 & 0.172 & 222.000 & 0.7748 & 32.8000 \\
\hline 5 & 0.139 & 228.000 & 0.6096 & 27.4076 \\
\hline 6 & 0.182 & 280.000 & 0.6500 & 30.3151 \\
\hline 7 & 0.140 & 298.000 & 0.4698 & 22.4194 \\
\hline 8 & 0.156 & 308.000 & 0.5065 & 24.5302 \\
\hline
\end{tabular}

Sumber: Peneliti, 2017

Dari Tabel 3 dapat dilihat karakteristik tahanan V/I air laut terhadap kedalaman elektroda seperti ditunjukkan oleh gambar 14 .

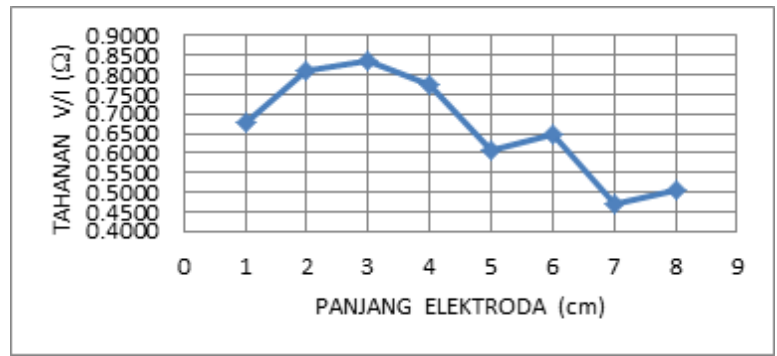

Sumber: Peneliti, 2017 


\section{JURNAL SIMETRIK VOL.8, NO.1, JUNI 2018}

\section{Gambar 14. Kurva tahanan V/I air laut vs kedalaman elektroda}

Nilai tahanan V/I air laut untuk kedalaman elektroda lebih kecil dari $4 \mathrm{~cm}$ berkisar antara $0,65 \Omega$ sampai dengan $0,85 \Omega$ sedangkan pada kedalaman lebih besar dari $4 \mathrm{~cm}$ tahanan tersebut mengecil hingga $0,45-\Omega$. Air laut merupakan material penghantar sehingga tahanan V/I-nya kecil sekali dibandingkan dengan pasir dan tanah. Dengan mengabaikan pengukuran pada $1-\mathrm{cm}$ yang mempunyai kendala karena pendeknya elektroda maka nilai tahanan air laut pada pengukuran lebih kecil dari $4 \mathrm{~cm}$ dianggap konstan dan berkisar pada nilai $0,8 \Omega$. Selanjutnya dengan menggunakan persamaan (2.3), maka diperoleh nilai tahanan jenis air laut sebagai fungsi dari kedalaman elektroda yang ditunjukkan oleh grafik gambar 15.

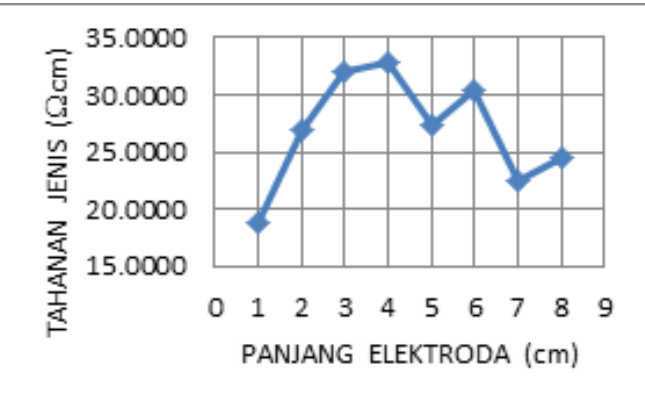

Sumber: Peneliti, 2017

\section{Gambar 15. Kurva tahanan jenis air laut vs kedalaman elektroda}

Hasil perhitungan tahanan jenis air laut berkisar antara $20 \Omega \mathrm{cm}$ sampai dengan $35 \Omega \mathrm{cm}$, terlihat bahwa tahanan jenis air laut sangat kecil dibandingkan dengan pasir dan tanah. Dengan bertambahnya kedalaman elektroda tahanan jenis air laut meningkat sampai kedalaman $4 \mathrm{~cm}$ selebihnya makin menurun pada daerah kedalaman elektroda lebih besar dari 4 $\mathrm{cm}$. Jadi rerata tahanan jenis air laut berada pada nilai $27 \Omega \mathrm{cm}$ atau $0,27 \Omega \mathrm{m}$. Hasil pengukuran ini menurut Khoirun Nisa, Tony Yulianto dan Sugeng Widada, 2012 adalah kategori air laut dengan nilai acuannya $0,2 \Omega \mathrm{m}$.

\section{PENUTUP}

\subsection{Kesimpulan}

Simpulan yang dapat diambil dari hasil penelitian ini adalah:

1. Hasil pengukuran untuk tanah makin dalam elektroda tahanan V/I makin kecil untuk kedalaman lebih kecil dari jarak elektroda, untuk kedalaman elektroda lebih besar dari jarak elektroda hasil pengukuran tahanan V/I konstan. Hasil pengukuran jahanan jenis tanah tidak berpengaruh terhadap kedalaman eletroda. Hasil perhitungan tahanan jenis tanah dari pengukuran dengan perubahan elektroda dari $1-\mathrm{cm} \mathrm{s} / \mathrm{d} 8 \mathrm{~cm}$ berkisar antara $4.000-\Omega \mathrm{cm}$ s/d $6.000-\Omega \mathrm{cm}$ yang p-ISSN: 2302-9579/e-ISSN: 2581-2866 reratanya berkisar $5.300 \Omega \mathrm{cm}$, tahanan jenis tanah nilainya tetap konstan dengan penambahan kedalaman elektroda.

2. Pengukuran untuk material pasir menunjukkan bahwa kedalaman elektroda lebih kecil dari $4 \mathrm{~cm}$ nilai tahanan $\mathrm{V} / \mathrm{I}$ konstan. Untuk kedalaman elektroda lebih besar dari jarak elektroda nilai tahanan V/I meningkat sebanding dengan kedalman eletroda. Tahanan jenis pasir bernilai konstan pada kedalaman lebih kecil dari jarak eletroda.

3. Pengukuran tahanan $\mathrm{V} / \mathrm{I}$ air laut konstan pada kedalaman eletroda lebih kecil dari jarak elektroda, selanjutnya akan mengecil bila elektroda semakin dalam. Semakin dalam eletroda, tahanan jenis air laut makin besar untuk kedalman elektroda lebih kecil dari jarak elektroda, untuk kedalaman eletroda lebih besar dari jarak elektroda pengukuran tahanan tahanan jenis air laut semakain kecil.

\subsection{Saran}

Penelitian ini hanya mengunakan satu ukuran jarak elektroda $(4 \mathrm{~cm})$, untuk mendapatkan hasil yang lebih teliti jarak elektroda dapat diperbesar yaitu kelipatan dari $4 \mathrm{~cm}$ sehingga arus listrik yang mengalir lebih dalam dan mencakup material yang lebih luas.

\section{DAFTAR PUSTAKA}

Aris Sunawar, 2013, Analisis Pengaruh Temperatur dan Kadar Garam terhadap Hambatan Jenis Tanah, Jurnal Setrum, ISSN: 2301-4652, vol. 2 , no. 1

Bulkis Kanata, Teti Zubaidah, 2008, Aplikasi Metode Geolistrik Tahanan Jenis Konfogurasi Wenner-Schlumberger untuk Survey Pipa Bawah Permukaan, Jurnal Teknologi Elektro, Vol. 7, No. 2, Juli-Desember 2008

Jamaaluddin, Izza Anshory, Eko Agus Suprayitno, 2015, Penentuan Kedalaman Elektroda pada Tanah Pasir dan Kerikil Kering untuk Memperoleh Nilai Tahanan Pentanahan yang Baik, Jte-U, Vol. 1, No. 1, Dzulhijjah 1436 H/Oktober 2015

Khoirun Nisa, Tony Yulianto dan Sugeng Widada, 2012, Aplikasi Metode Geolistrik Tahanan Jenis untuk Menentukan Zona Intrusi Air Laut di Kecamatan Genuk Semarang Berkala Fisika Issn : 1410 - 9662 Vol. 15, No. 1, Januari 2012, Hal 7- 14

Managam Rajagukguk, 2012, Studi Pengaruh Jenis Tanah Dan Kedalaman Pembumian Driven Rod Terhadap Resistansi Jenis Tanah, Vokasi Issn 1693 - 9085 Volume 8, Nomor 2, Juni 2012 Hal $121-132$

Rina Dwi Indriana dan Hernowo Danusaputro, 2006, Uji Nilai Tahanan Jenis Polutan Air Laut dengan Metode Ohmik dan Geolistrik 
Tahanan Jenis Skala Laboratorium, Jurnal Berkala Fisika, ISSN: 1410-9662, vol. 9, no. 3, hal. 145-149

Wahyono dan Budhi Prasetiyo, Analisa Pengaruh Jarak dan Kedalaman terhadap Nilai Tahanan Pembumian dengan 2 Elemen Batang, ISBN: 978-602-99334-2-0

Earthing Techniques Paper, Lightning and Surge Technologies

AEMC Instrumenthttps:// www. Global testsupply.com/content/aemc-understandingsoil-resistivity-testing.Html(25-05-2017)

http://arifpanduwinata.blogspot.co.id/2012/06/metodetahanan-jenis-geolistrik.html 07-05-2017)

httpdigilib.itb.ac.idfilesdisk1542jbptitbpp-gdlsyamsudinn-27079-2-2007ts-.pdf, (07-052017)

https://ptbudie.com/2010/12/24/geolistrik/ (07-052017) 